\title{
PREVALENCE OF CELIAC DISEASE IN SIBLINGS OF IRANIAN PATIENTS WITH CELIAC DISEASE
}

\author{
Bashir CHOMEILI ${ }^{1}$, Majid AMINZADEH ${ }^{2}$, Amir Kamal HARDANI ${ }^{1}$, \\ Payam FATHIZADEH ${ }^{3}$, Pooya CHOMEILI ${ }^{1}$ and Azarakhsh AZARAN ${ }^{3}$
}

\begin{abstract}
Context - Celiac disease, one of the best-known autoimmune human leukocyte antigen-dependent disorders, has a relatively increased prevalence in first-degree relatives. Objective - To determine the prevalence of celiac disease in siblings of patients with confirmed celiac disease. Methods - Siblings of confirmed celiac disease patients in our center were identified and enrolled in this study. Their serum immunoglobulin A and tissue transglutaminase antibody-enzyme-linked immunosorbent assay (anti-tissue transglutaminase, immunoglobulin A, and immunoglobulin G) were measured and multiple endoscopic duodenal biopsy specimens were obtained with parental consensus. Celiac disease was confirmed by observation of characteristic histological changes. Results A total of 49 children (male, 29; female, 20; age, 2-16 years) with confirmed celiac disease in a pediatric gastroenterology ward were studied from 1999 to 2006 . We found 30 siblings (female, 16) all shared in both parents. The only measurement available was for immunoglobulin A tissue transglutaminase antibody. A duodenal biopsy was performed in all 30 siblings. Clinical findings such as abdominal pain, fatigue, growth retardation and diarrhea were found in $53.3 \%$ of the completely studied siblings, and positive serology without histological changes was identified in four cases. Both serology and biopsy (confirmed new cases) were positive in 2 of the 30 siblings. Conclusion - High prevalence of celiac disease among siblings of patients with confirmed celiac disease necessitates serologic screening (and confirmatory biopsy if indicated) in families having celiac disease. It is advantageous to diagnose the disease as soon as possible because early diagnosis and diet intervention may prevent serious complications such as growth retardation, short stature, chronic diarrhea, and malignancy.
\end{abstract}

HEADINGS - Celiac disease, epidemiology. Siblings. Iran.

\section{INTRODUCTION}

Celiac disease (CD), a permanent sensitivity to gliadin, is a common chronic and autoimmune disorder with different frequencies in different geographical areas ${ }^{7}$, $10,14,16,20)$. The prevalence of $\mathrm{CD}$ exhibits an iceberg effect; the number of asymptomatic cases with positive serology and biopsy is 5- to 7-fold higher than typical symptomatic individuals exhibiting signs and symptoms including abdominal pain, growth retardation, short stature, chronic diarrhea, iron deficiency anemia that is refractive to treatment and intestinal lymphoma ${ }^{(6,12 \text {, }}$ ${ }^{21}{ }^{29}$. Serologic tests such as the anti-endomysium IgA antibody test (EMA), the anti-tissue transglutaminase immunoglobulin (Ig) A antibody test (anti-tTG Ab) and HLA DQ2 or DQ8 genotype testing are useful for evaluation of asymptomatic subjects as well as patients with diabetes mellitus, thyroiditis, Down syndrome, Turner syndrome, William syndrome, IgA deficiency and first-degree relatives of patients with $\mathrm{CD}^{(1,4,5,17)}$.
It is therefore logical to screen these populations for other autoimmune diseases. Anti-gliadin antibody, antiendomysium antibody and anti-tissue transglutaminase antibody (anti-tTG $\mathrm{Ab}$ ) are the most popular serologic tests used for this screening ${ }^{(15,19)}$. However, some researchers believe that positive anti-tTG Ab is sufficient to diagnose CD in up to $80 \%$ of cases. Since these antibodies may also be found in normal risk-free children, the consensus is still in favor of performing a duodenal biopsy and identifying typical histological changes. This analysis has been considered the gold standard for diagnosis of $\mathrm{CD}^{(30)}$. All available data are from Western populations, but Eastern areas have higher rates of consanguineous marriage, which is an additional risk factor for disorders like CD. This study aimed to identify a prevalence of typical CD among siblings of children confirmed previously to have CD and to compare the predictive value of a serologic test with intestinal histopathological evidence for diagnosing a new case in the same family.

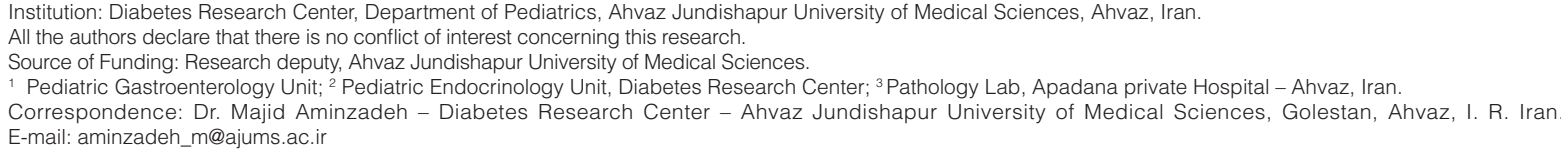




\section{METHODS}

Siblings of confirmed CD patients living in Khuzestan province in southwestern Iran, who were diagnosed by or referred to the authors between 1999 and 2006, were enrolled in this study. Criteria for diagnosis of CD were as follows: clinical findings including growth retardation, short stature, abdominal pain and/or distension, proximal muscle atrophy, chronic diarrhea and fatigue, along with serologic tests and confirmation by duodenal biopsy results. A comprehensive discussion was conducted with the parents on the subject of the disease and the importance and necessity of screening in high risk but apparently healthy first-degree relatives with a particular emphasis on siblings. Signed written consent was obtained from the parents.

The study was approved (Approval No. p/8/20/437) by the ethical committee of Ahvaz Jundishapur University of Medical Sciences (AJUMS), Iran. In addition to a physical

TABLE 1. Details of the studied siblings of known cases of celiac disease

\begin{tabular}{|c|c|c|c|c|c|c|c|}
\hline Case No. & Sex & Age/Y & Sign \& symptom & $\begin{array}{l}\text { Anti- tTG } \\
\text { Ab level* }\end{array}$ & 1st DUO.Biopsy & 2nd DUO.Biopsy & $\begin{array}{c}\text { Final diagnosis } \\
\text { and action }\end{array}$ \\
\hline 1 & $\mathrm{M}$ & 6 & None & $8.2 *$ & Neg & ND & AFU \\
\hline 2 & $\mathrm{~F}$ & 5 & None & 2.9 & Neg & $\mathrm{ND}$ & AFU \\
\hline 3 & $\mathrm{~F}$ & 8 & CAP, SS & 1222 & CD & CD & $\mathrm{CD}, \mathrm{Tx}$ \\
\hline 4 & $\mathrm{~F}$ & 4 & D & 508 & $\mathrm{CD}$ & $\mathrm{CD}$ & $\mathrm{CD}, \mathrm{Tx}$ \\
\hline 5 & M & 14 & $\mathrm{P}, \mathrm{A}$ & 18.9 & Neg & $\mathrm{ND}$ & AFU \\
\hline 6 & $\mathrm{M}$ & 13 & None & 6.8 & Neg & $\mathrm{ND}$ & AFU \\
\hline 7 & $\mathrm{M}$ & 3 & None & 6.2 & Neg & $\mathrm{ND}$ & AFU \\
\hline 8 & $\mathrm{~F}$ & 5 & PD & 3.5 & Neg & ND & AFU \\
\hline 9 & $\mathrm{M}$ & 2 & None & 2.4 & Neg & ND & AFU \\
\hline 10 & $\mathrm{M}$ & 3 & None & 3 & Neg & $\mathrm{ND}$ & AFU \\
\hline 11 & $\mathrm{M}$ & 3 & None & 5.7 & NA & $\mathrm{ND}$ & AFU \\
\hline 12 & $\mathrm{~F}$ & 6 & F & 2.4 & Neg & ND & AFU \\
\hline 13 & $\mathrm{M}$ & 12 & F,CAP, A & 113 & S & refused & AFU \\
\hline 14 & $\mathrm{~F}$ & 3 & None & 2.4 & Neg & ND & AFU \\
\hline 15 & $\mathrm{M}$ & 7 & None & 5.3 & Neg & ND & AFU \\
\hline 16 & $\mathrm{M}$ & 5 & $\mathrm{PD}, \mathrm{D}, \mathrm{P}$ & 26.1 & Neg & ND & AFU \\
\hline 17 & $\mathrm{M}$ & 3 & None & 5 & NA & ND & AFU \\
\hline 18 & $\mathrm{~F}$ & 6 & PD & 18.9 & $\mathrm{~S}$ & refused & AFU \\
\hline 19 & $\mathrm{M}$ & 5 & $\mathrm{SS}, \mathrm{P}$ & 6.6 & Neg & $\mathrm{ND}$ & AFU \\
\hline 20 & $\mathrm{~F}$ & 12 & None & 2.1 & Neg & $\mathrm{ND}$ & AFU \\
\hline 21 & $\mathrm{M}$ & 7 & None & 3.7 & NA & $\mathrm{ND}$ & AFU \\
\hline 22 & $\mathrm{~F}$ & 2 & None & 2.6 & NA & ND & AFU \\
\hline 23 & $\mathrm{~F}$ & 13 & C & 2.6 & Neg & $\mathrm{ND}$ & AFU \\
\hline 24 & $\mathrm{~F}$ & 4 & None & 3.6 & Neg & $\mathrm{ND}$ & AFU \\
\hline 25 & M & 5 & $\mathrm{I}, \mathrm{F}, \mathrm{SS}$ & 1.6 & Neg & $\mathrm{ND}$ & AFU \\
\hline 26 & M & 6 & None & 8.7 & Neg & $\mathrm{ND}$ & AFU \\
\hline 27 & M & 10 & I, D, CAP,PD & 82.6 & Neg & $\mathrm{ND}$ & AFU \\
\hline 28 & $\mathrm{M}$ & 7 & None & 2.3 & NA & $\mathrm{ND}$ & AFU \\
\hline 29 & $\mathrm{M}$ & 3 & None & 5.8 & Neg & $\mathrm{ND}$ & AFU \\
\hline 30 & $\mathrm{M}$ & 5 & None & 15.2 & Neg & $\mathrm{ND}$ & AFU \\
\hline 31 & $\mathrm{~F}$ & 2 & CAP & 2.5 & Neg & $\mathrm{ND}$ & AFU \\
\hline 32 & M & 16 & None & 1.1 & NA & $\mathrm{ND}$ & AFU \\
\hline 33 & $\mathrm{~F}$ & 14 & A & 7.8 & Neg & $\mathrm{ND}$ & AFU \\
\hline 34 & $\mathrm{M}$ & 14 & CAP, A, F & $>600$ & $\mathrm{~S}$ & Neg & AFU \\
\hline 35 & $\mathrm{M}$ & 7 & None & 4.4 & NA & $\mathrm{ND}$ & AFU \\
\hline 36 & $\mathrm{~F}$ & 10 & CAP & 24.9 & Neg & $\mathrm{ND}$ & AFU \\
\hline 37 & $\mathrm{M}$ & 3 & None & 2 & NA & $\mathrm{ND}$ & AFU \\
\hline 38 & $\mathrm{~F}$ & 5 & None & 8.2 & $\mathrm{~S}$ & Neg & AFU \\
\hline 39 & $\mathrm{M}$ & 5 & None & 1.8 & NA & ND & AFU \\
\hline
\end{tabular}

Abbreviations: DUO: duodenal; CAP: chronic abdominal pain; A: anorexia; F: fatigability; PD: pallor \& dizziness; D: diarrhea; P: poor weight gain; SS: short stature; I: impatience; C: constipation; CD: celiac disease; Tx: treatment; S: suspicious; NA: did not attend; AFU: advised follow up; N: normal; Neg: negative; ND: not done

$* \mathrm{U} / \mathrm{mL}$ 
examination, a history of possible signs of CD was obtained and auxiliary data were collected from all individuals. A full laboratory assessment (cell blood count, erythrocyte sedimentation rate, blood urea nitrogen (BUN), creatinine, urinalysis, and stool examination for parasites, leukocytes, occult blood, etc.) was performed in all patients to rule out other possible systemic or gastrointestinal diseases. Serologic screening was performed by assessment of serum IgA (to identify possible selective IgA-deficient subjects) and anti-tTG (IgA and $\operatorname{IgG}$ ). We used the Celi-check kit (Germany), ELISA method, and ELISA reader (ELx800, BIO-TEK Instruments, Inc., USA). Blood samples were obtained following overnight fasting and kept at $-20^{\circ} \mathrm{C}$ until the laboratory procedures were performed. As recommended by the manufacturer, we established our own normal range based upon our technique, control, equipment, and patient population according to our own established procedure. Our laboratory setting processed a cutoff point of $20 \mathrm{U} / \mathrm{mL}$. Additional results $(\geq 20 \mathrm{U} / \mathrm{mL})$ were considered as positive for anti-tTG. HLA typing facilities were not available for selecting siblings for duodenal biopsy, so endoscopy and duodenal biopsy were performed using an Olympus endoscope on the same day that the serology test was performed to avoid observer bias for all of the 30 siblings in the study. A duodenal biopsy specimen with a villus/crypt (v/c) ratio higher than 3 (without infiltration of chronic inflammatory cells) was considered as normal, whereas a decrease of $\mathrm{v} / \mathrm{c}$ along with infiltration of the lamina propria with several degrees of chronic inflammatory cells indicated a diagnosis of varying degrees of atrophy as follows: 2.5 to 1.5 , mild villus atrophy; 1 to 0.5 , moderate (partial) villus atrophy; and less than 0.5 , severe (subtotal/ total) villus atrophy. The sample was reported as suspicious if, in addition to intraepithelial infiltration, assessment of the $\mathrm{v} / \mathrm{c}$ was not possible because of inappropriate orientation or absence of muscularis mucosa.

\section{RESULTS}

The study originally included 49 confirmed CD patients since 1999 to 2006 (29 males, 20 females; mean age, $7.5 \pm 2.5$ years). We were not able to locate 7 families as a result of a change in address or loss of follow-up documentation. Two families chose to not participate and in 7 other families the index case was an only child. As a result, 39 children from 33 remaining families were enrolled in this study. Nine children did not permit an endoscopic biopsy and were excluded. This left 30 children (16 males, 14 females) participate in the study. Details of the siblings who participated are provided in Table 1. One or multiple clinical signs or symptoms were found in 53.3\% ( 7 males, 9 females) of the 30 siblings (Table 2). Abnormal tTG was identified in $44 \%$ ( 4 males, 3 females) of the 16 siblings with clinical signs and symptoms (Table 3 ) and in $33 \%$ of the 30 studied siblings. Two girls $(6.6 \%)$ had characteristic intestinal changes compatible with diagnosis of CD (presence of both intraepithelial infiltration and villus atrophy). Serology also was positive in both. Four biopsy samples (from two males and two females) were suspicious,
TABLE 2. Frequency and sex distribution of clinical signs or symptoms in 16 of 30 siblings of the studied patients with celiac disease

\begin{tabular}{lccc}
\hline Signs \& symptoms & $\%$ & Female & Male \\
\hline Abdominal pain & 37.5 & 3 & 3 \\
Anorexia & 25 & 1 & 3 \\
Fatigability & 25 & 1 & 3 \\
Pallor and dizziness & 25 & 2 & 2 \\
Diarrhea & 18.75 & 1 & 2 \\
Poor weight gain & 18.75 & - & 3 \\
Short stature & 18.75 & 1 & 2 \\
Impatience & 12.5 & - & 2 \\
Constipation & 6.25 & 1 & - \\
\hline
\end{tabular}

Note: There was more than one sign or symptom in some patients

TABLE 3. Results of serology and biopsy in 9 (of 16 clinically involved) siblings

\begin{tabular}{lcccc}
\hline Sex & Age & Anti-tTG & Biopsy & Comment \\
\hline F & 8 & + & definite & treatment \\
F & 4 & + & definite & treatment \\
M & 14 & - & suspicious & 2nd biopsy, did not attend \\
F & 10 & + & suspicious & 2nd biopsy, did not attend \\
M & 12 & + & suspicious & 2nd biopsy, negative \\
F & 5 & - & suspicious & 2nd biopsy, negative \\
M & 5 & + & negative & follow-up \\
M & 10 & + & negative & follow-up \\
M & 5 & + & negative & follow-up \\
\hline
\end{tabular}

$\mathrm{M}=$ Male;

$\mathrm{F}=$ Female;

anti-tTG antibody $\geq 20$ IU considered +

and after recommendation for a second biopsy, two individuals refused whereas the other two were found to have normal histology in a second biopsy.

\section{DISCUSSION}

Several studies have performed screening of CD in high-risk populations. People at higher risk than normal individuals tend to have Down syndrome, Turner syndrome, selective IgA deficiency or other autoimmune diseases such as diabetes mellitus and dermatitis herpetiformis. First-degree relatives of subjects with $\mathrm{CD}$ are also at a higher risk for $\mathrm{CD}^{(2,13)}$. The frequency of $\mathrm{CD}$ in the general population depends upon the geographical area (environmental factors) and ethnicity

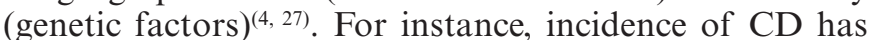
been reported as high as $0.01 \%-0.5 \%$ and $1.2 \%$ of the total population in Sweden and England, respectively. Rates are higher in Arabian countries, with $0.5 \%-1.0 \%$ of the total population having $\mathrm{CD}^{(11)}$. There have been on reports on the frequency of $\mathrm{CD}$ in Iran. This difference in prevalence suggests the presence of different risks in high-risk groups as well. Some other factors such as the higher incidence of consanguineous marriage in Middle Eastern countries may increase these frequencies significantly. HLA typing is mainly used for diagnosing CD in cases with doubtful clinical, 
serologic, and histological findings. This can be performed by several methods, but it is costly and time consuming ${ }^{(31)}$. Recently, a new method involving HLA typing of six single nucleotide polymorphism (SNPs) has been found to be efficient and cost-effective. The increased sensitivity and specificity of this method increases the chances of identifying CD in high-risk populations ${ }^{(18)}$.

Because all serologic tests are based upon assessments of serum IgA (using mucosal antibody against gliadin) and one of the high-risk groups has IgA deficiency, each serology test should be accompanied with a measurement of native $\operatorname{IgA}$ at the same time. Sensitivity and specificity of IgA-Ab to tTG has been reported to be sufficiently high to be considered as a diagnostic test in about $80 \%$ of situations where obtaining a biopsy is not possible ${ }^{(8,28)}$. The specificity of the anti-tTG Ab is not significantly different from that of the anti-endomysium antibody, but we prefer it because it requires fewer operators. The gold standard for diagnosis is histopathology of biopsy specimens, accompanied by clinical and histological response to a gliadin-free diet and then recurrence of histological findings after the gliadin rechallenge test, which is particularly important for children below 2 years of age ${ }^{(9,23,24)}$. This method of confirmation is difficult for everyone. Therefore, in this study, as in many others, only one typical histological finding has been considered for confirmation of the presence of the disease. Therefore, in two newly diagnosed cases of $\mathrm{CD}$, we considered the clinical response (observed following administration of a gluten-free diet) as the final confirmation of the diagnosis. Biopsy is recommended even when negative results are obtained in serologic screening when suspicious clinical signs or symptoms are evident ${ }^{(3,25)}$. A similar study was performed using HLA typing and small bowel histology in Asian first-degree relatives of children with CD by Srivastava et al. ${ }^{(26)}$. This study identified a $4.4 \%$ prevalence of histologically confirmed CD. Our confirmed prevalence was $6.6 \%$. Unfortunately, the genetic test and HLA typing were not available at the time our study was performed. On the basis of the rules and limitations described above, with respect to the routine screening methods for $\mathrm{CD}$, it was necessary to screen all siblings with anti-tTG Ab and perform endoscopy with duodenal biopsy at the same time. These analyses were performed in a double-blinded fashion. We do not recommend intestinal biopsy to screen $\mathrm{CD}$ in all cases when HLA typing and serologic testing are available. A better option would be to use the flow chart prepared by Srivastava et al. ${ }^{(26)}$.

This study performs both serology and biopsy screening. These data can be used also for assessing the value of serologic screening in high-risk individuals. Seven patients $(23.3 \%)$ were found to have positive tTG, but only 2 of 7 (6.6\% of all enrolled 30 cases) were confirmed by biopsy. However, 2 of the patients with suspicious biopsies refused follow-up when a second biopsy was recommended. Suspicious biopsies were repeated immediately to rule out the possibility of inappropriate sampling (method or place) or preparation.
Our results are comparable with those of other Western studies that show a $2 \%-6 \%$ prevalence of clinical CD and up to $10 \%$ intestinal involvement without clinical signs in first-degree relatives of individuals with $\mathrm{CD}^{(5,7,21)}$. On the other hand, compatibility of anti-tTG antibody and biopsy has been reported to be $80 \%-95 \%$ in some studies ${ }^{(5,22,29)}$, but was found to be $58.8 \%$ in our study (this includes the refusal of follow-up in two patients with suspicious first biopsies). Some studies have reported that a subject with a negative biopsy but a positive anti tTG Ab (similar to case numbers 27 and 34 in our study - (Table 1)) could be classified as a CD patient in the future. Follow-up of such patients and duodenal biopsy is recommended. We advised the members of our study group to schedule follow-up visits in the future.

We were unable to find any other study performed in Iran that was similar to the present study. The low positive predictive value of anti-tTG $\mathrm{Ab}$ for true histologic $\mathrm{CD}$ (discrepancy between serologic and histological disease) in the present study (two of seven) in comparison with other studies may be rationalized as follows: (i) as the frequency of disease in a high-risk population increases, it may lead to a higher frequency of autoimmunity alone (positive serology without intestinal disease), which would be indicated by an increased prevalence of islet cell auto antibodies in first-degree relatives of diabetic patients relative to the normal population. (ii) Because CD can develop in elderly individuals, there is a possibility that some of the serologically positive cases progress to true disease in the future. Long-term follow-up and biopsy over subsequent years will identify additional histologically positive cases in these families. This could be considered also for siblings with negative anti tTG antibody. (iii) We might have lost two cases of true CD because two individuals with suspicious biopsies refused a second biopsy. (iv) Autoimmunity alone is a very mild form of disease on one side of the wide spectrum of this pathology. (v) Except for two of the Ab-positive subjects (cases no. 16 and 36), all others had very high levels of serum $\mathrm{Ab}$, so inappropriate techniques or cutoffs could not be the cause of this discrepancy. Finally, the unavailability of genetic testing and HLA typing, the loss of follow-up because of relocation of families, unavailability of other families, and refusal to participate in re-testing or to provide biopsies must be considered as limitations of this study.

\section{CONCLUSION}

The high prevalence $(6.6 \%)$ of $\mathrm{CD}$ in siblings of patients with CD identified in this study and other studies confirm the necessity and importance of instituting a screening program for first-degree relatives of children with $\mathrm{CD}$ to identify the disease and administer a strict gluten-free diet to prevent serious complications.

\section{ACKNOWLEDGEMENTS}

The authors wish to thank the Vice Chancellor of research of Ahvaz Jundishapur University of Medical Sciences for financial support. 
Chomeili B, Aminzadeh M, Hardani AK, Fathzadeh P, Chomeili P, Azaran A. Prevalência de doença celíaca em filhos de pais iranianos com doença celíaca. Arq Gastroenterol. 2011;48(2):131-5.

RESUMO - Contexto - A doença celíaca, uma das mais conhecidas enfermidades autoimunes humanas, leucocitária antígeno-dependente, tem prevalência relativamente maior em parentes de primeiro grau. Objetivo - Determinar a prevalência de doença celíaca em irmãos de pacientes confirmadamente celíacos, filhos dos mesmos pais. Métodos - Os irmãos de pacientes com doença celíaca confirmada no Department of Pediatrics, Ahvaz Jundishapur University of Medical Sciences, em Ahvaz, Iran, foram identificados e incluídos no estudo. A imunoglobulina A sérica e o anticorpo transglutaminase tecidual por ensaio imunoenzimático (anti-transglutaminase tecidual, imunoglobulina A e imunoglobulina G) foram medidos e múltiplas biopsias endoscópicas duodenais foram obtidas com o consenso dos pais. A doença celíaca foi confirmada pela observação das características histológicas. Resultados - Um total de 49 crianças (29 do sexo masculino; 20 do sexo feminino; de 2 a 16 anos) com diagnóstico confirmado de doença celíaca em uma enfermaria de gastroenterologia pediátrica foi estudado de 1999 a 2006. Encontraram-se 30 irmãos (16 do sexo feminino) e todos compartilhavam os mesmos pais dos pacientes. A única medida disponível foi do anticorpo tecidual imunoglobulina A transglutaminase. A biopsia duodenal foi realizada em todos os 30 irmãos. As manifestações clínicas como dor abdominal, fadiga, retardo do crescimento e diarréia foram encontradas em $53,3 \%$ dos irmãos estudados completamente, e a sorologia positiva sem alterações histológicas foi identificada em quatro casos. Ambas, sorologia e biopsia (novos casos confirmados) foram positivas em 2 dos 30 irmãos. Conclusão - A prevalência de doença celíaca entre irmãos de pais confirmadamente celíacos exige triagem sorológica e biopsia de confirmação, se indicada, em familiares com doença celíaca. Diagnosticar a doença o mais rápido possível traz vantagens, pois o diagnóstico precoce e a intervenção dietética podem prevenir complicações graves, como retardo do crescimento, baixa estatura, diarreia crônica e malignidade.

DESCRITORES - Doença celíaca, epidemiologia. Irmãos. Irã.

\section{REFERENCES}

1. Blackwell PJ, Hill PG, Holmes GK. Autoantibodies to human tissue transglutaminase: superior predictors of coeliac disease. Scand J Gastroenterol. 2002;37:1282-5.

2. Book L, Zone JJ, Neuhausen SL. Prevalence of celiac disease among relatives of sib pairs with celiac disease in U. S. families. Am J Gastroenterol. 2003;98:377-81.

3. Branski D, Fasano A, Troncone R. Latest developments in the pathogenesis and treatment of celiac disease. J Pediatr. 2006;149:295-300.

4. Carnicer J, Farré C, Varea V, Vilar P, Moreno J, Artigas J. Prevalence of coelic disease in Down's syndrome. Eur J Gastroenterol Hepatol. 2001;13:263-7.

5. Cataldo F, Marino V. Increased prevalence of autoimmune disease in firstdegree relatives of patients with celiac disease. J Pediatr Gastroenterol Nutr. 2003;36:470-3.

6. Catassi C, Bearzi I, Holmes GK. Association of celiac disease and intestinal lymphomas and other cancers. Gastroenterology. 2005;128:S79-86.

7. Ertekin V, Selimoğlu MA, Kardaş F, Aktaş E. Prevalence of celiac disease in Turkish children. J Clin Gastroenterol. 2005;39:689-91.

8. Farrell RJ, Kelly CP. Celiac sprue. N Engl J Med. 2002;346:180-8.

9. Fasano A, Catassi C. Current approaches to diagnosis and treatment of celiac disease: an evolving spectrum. Gastroenterology. 2001;120:636-51.

10. Fasano A, Berti I, Gerarduzzi T, Not T, Colletti RB, Drago S, Elitsur Y, Green PH, Guandalini S, Hill ID, Pietzak M, Ventura A, Thorpe M, Kryszak D, Fornaroli F, Wasserman SS, Murray JA, Horvath K. Prevalence of celiac disease in at-risk and not-at-risk groups in the United States: a large multicenter study. Arch Intern Med. 2003;163:286-92.

11. Fasano A, Catassi C. Coeliac disease in children. Best Pract Res Clin Gastroenterol. 2005;19:467-78.

12. Green PH, Fleischauer AT, Bhagat G, Goyal R, Jabri B, Neugut AI. Risk of malignancy in patients with celiac disease. Am J Med. 2003;115:191-5.

13. Gudjonsdottir AH, Nilsson S, EK J, Kristiansson B, Ascher H. The risk of celiac disease in 107 families with at least two affected siblings. J Pediatr Gastroenterol Nutr. 2004;38:338-42.

14. Hill I, Fasano A, Schwartz R, Counts D, Glock M, Horvath K. The prevalence of celiac disease in at-risk groups of children in the United States. J Pediatr. 2000;136:86-90

15. Hill ID, Dirks MH, Liptak GS, Colletti RB, Fasano A, Guandalini S, Hoffenberg EJ, Horvath K, Murray JA, Pivor M, Seidman EG; North American Society for Pediatric Gastroenterology, Hepatology and Nutrition. Guideline for the diagnosis and treatment of celiac disease in children: recommendation of the North American Society for Pediatric Gastroenterology, Hepatology and Nutrition. J Pediatr Gastroenterol Nutr. 2005;40:1-19.

16. Hoffenberg EJ, MacKenzie T, Barriga KJ, Eisenbarth GS, Bao F, Haas JE, Erlich H, Bugawan Tl T, Sokol RJ, Taki I, Norris JM, Rewers M. A prospective study of the incidence of childhood celiac disease. J Pediatr. 2003;143:308-14. 17. Kagnoff MF. Celiac disease: pathogenesis of a model immunogenetic disease. J Clin Invest. 2007;117:41-9.

18. Koskinen L, Romanos J, Kaukinen K, Mustalahti K, Korponay-Szabo I, Barisani D, Bardella MT, Ziberna F, Vatta S, Széles G, Pocsai Z, Karell K, Haimila K, Adány R, Not T, Ventura A, Mäki M, Partanen J, Wijmenga C, Saavalainen P. Cost-effective HLA typing with tagging SNPs predicts celiac disease risk haplotypes in the Finnish, Hungarian, and Italian populations. Immunogenetics. 2009;61:247-56.

19. Liu E, Li M, Bao F, Miao D, Rewers MJ, Eisenbarth GS, Hoffenberg EJ. Need for quantitative assessment of transglutaminase autoantibodies for celiac disease in screening-identified children. J Pediatr. 2005;146:494-9.

20. Mäki M, Mustalahti K, Kokkonen J, Kulmala P, Haapalahti M, Karttunen T, Ilonen J, Laurila K, Dahlbom I, Hansson T, Höpfl P, Knip M. Prevalence of celiac disease among children in Finland. N Engl J Med. 2003;348:2517-24.

21. McOmber ME, Shulman RJ. Recurrent abdominal pain and irritable bowel syndrome in children. Curr Opin Pediatr. 2007;19:581-5.

22. Mearin ML. Celiac disease among children and adolescents. Curr Probl Pediatr Adolesc Health Care. 2007;37:86-105.

23. Norris JM, Barriga K, Hoffenberg EJ, Taki I, Miao D, Haas JE, Emery LM, Sokol RJ, Erlich HA, Eisenbarth GS, Rewers M. Risk of celiac disease autoimmunity and timing of gluten introduction in the diet of infants at increased risk of disease. JAMA. 2005;293:2343-51.

24. Revised criteria for diagnosis of coeliac disease. Report of Working Group of European Society of Paediatric Gastroenterology and Nutrition. Arch Dis Child. 1990;65:909-11.

25. Shamir R. Advances in celiac disease. Gastroenterol Clin North Am. 2003;32:931-47.

26. Srivastava A, Yachha SK, Mathias A, Parveen F, Poddar U, Agrawal S. Prevalence, human leukocyte antigen typing and strategy for screening among Asian first-degree relatives of children with celiac disease. J Gastroenterol Hepatol. 2010;25:319-24.

27. Sulkanen S, Halttunen T, Laurila K, Kolho KL, Korponay-Szabó IR, Sarnesto A, Savilahti E, Collin P, Mäki M. Tissue transglutaminase enzyme-linked immunosorbent assay in detecting celiac disease. Gastroenterology. 1998;115:1322-28.

28. Troncone R, Maurano F, Rossi M, Micillo M, Greco L, Auricchio R, Salerno G, Salvatore F, Sacchetti L. IgA antibodies to tissue transglutaminase: an effective diagnostic test for celiac disease. J Pediatr. 1999;134:166-71.

29. van Rijn JC, Grote FK, Oostdijk W, Wit JM. Short stature and the probability of coeliac disease, in the absence of gastrointestinal symptoms. Arch Dis Child. 2004;89:882-3.

Received 30/8/2010 Accepted 28/12/2010. 